\section{Geology, geomorphology, and the restoration ecology of salmon}

David R. Montgomery, Quaternary Research Center and Department of Earth \& Space Sciences, University of Washington, Seattle, Washington 98195-1310, USA

\section{ABSTRACT}

Natural and anthropogenic influences on watershed processes affect the distribution and abundance of salmon across a wide range of spatial and temporal scales, from differences in species use and density between individual pools and riffles to regional patterns of threatened, endangered, and extinct runs. The specific impacts of human activities (e.g., mining, logging, and urbanization) vary among regions and watersheds, as well as between different channel reaches in the same watershed. Consequently, recognizing and diagnosing the nature and causes of differences between historical and contemporary fluvial and watershed conditions and processes can require careful evaluation of both historical and spatial contexts. In order to be most effective, the contribution of geomorphological insights to salmon recovery efforts requires both assessment protocols commensurate with providing adequate knowledge of context, and experienced practitioners well versed in adapting general theory to local settings. The substantial influences of watershed processes on salmon habitat and salmon abundance indicate the need to incorporate insights from geology and geomorphology into salmon recovery efforts.

\section{INTRODUCTION}

Salmon have been extirpated across almost half of their historic range in the continental United States (Nehlsen et al., 1991) and individual species are considered as either threatened or en- dangered under the federal Endangered Species Act throughout much of their remaining range in California, the Pacific Northwest, and New England. Fishing pressure, ocean conditions, and the amount, condition, and accessibility of freshwater habitat all affect salmon abundance, and these historic anthropogenic influences on declining salmon populations are often lumped into the so-called four Hs of harvest (overfishing), hydro (dams), hatcheries, and habitat. Regionally, however, the size of salmon populations relative to their historical levels tracks the extent and intensity of human development: New England's Atlantic salmon (Salmo salar) have dwindled to $<1 \%$ of their historical population and Pacific salmon (Oncorbynchus spp.) account for $<10 \%$ of their historical abundance in the continental United States, whereas Alaska's Pacific salmon are thought to exceed their historical population (Table 1). Although all four Hs contributed to the decline of salmon in differing (and often unknown) proportions in different watersheds, the general correspondence between the overall condition of salmon populations and the extent of historical

TABLE 1. AVERAGE OF ESTIMATED HISTORIC AND CURRENT SALMON POPULATIONS IN DIFFERENT REGIONS

\begin{tabular}{lccc}
\hline \hline Region & $\begin{array}{c}\text { Historic } \\
(1000 \mathrm{~s} \text { of fish })\end{array}$ & $\begin{array}{c}\text { Current } \\
(1000 \mathrm{~s} \text { of fish })\end{array}$ & $\begin{array}{c}\text { Current/Historic } \\
(\%)\end{array}$ \\
\hline Alaska & 175,160 & 187,470 & $>100$ \\
British Columbia & 68,556 & 24,800 & 36 \\
California & 3,060 & 270 & 9 \\
Puget Sound & 20,036 & 1600 & 8 \\
Oregon Coast & 3,074 & 213 & 7 \\
Columbia River & 13,072 & 221 & 2 \\
Washington Coast & 3,935 & 72 & $<2$ \\
\hline
\end{tabular}

Note: Data from Gresh et al. (2000).

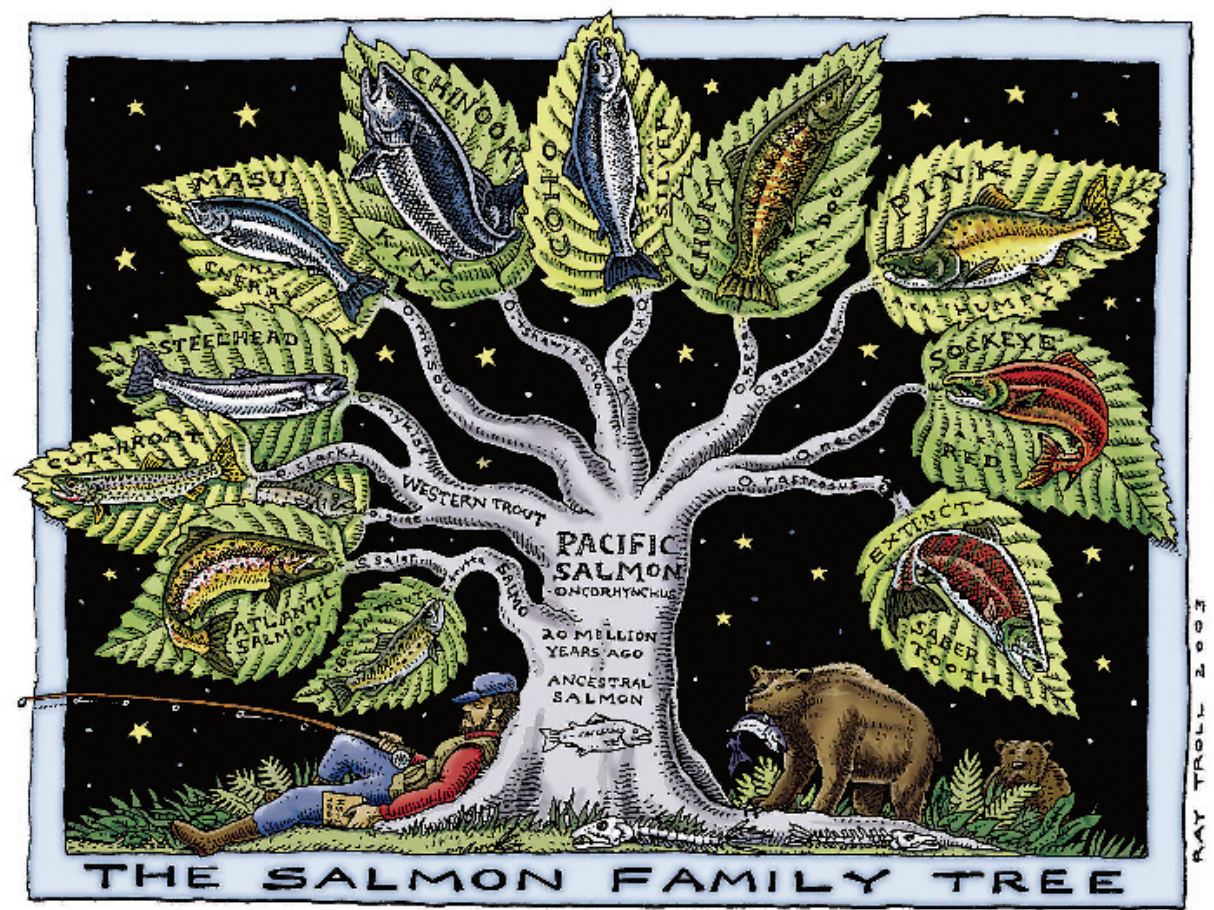

Figure 1. Phylogeny of the Salmoninae (Stearly and Smith, 1993) as drawn by Ray Troll (C2003 Ray Troll). 
changes to their river systems implicates habitat degradation as a major factor in historic decreases in salmon abundance (Frissell, 1993). Consequently, insights from geomorphology and geology, as well as ecology, are essential for designing river restoration measures intended to benefit salmon and their ecosystems.

The salmon's life cycle involves residing in fresh water as juveniles before migrating through whole river systems to and from the sea and then finally returning to their natal stream to spawn and die. This characteristic life history makes their abundance strongly dependent on the condition and disturbance history of their home stream and its watershed. Although huge sums are being spent in attempts to restore rivers and salmon in the continental United States_between 2001 and 2003 more than $\$ 130$ million was spent on salmon habitat restoration and enhancement projects in Washington State alonemany projects fail due to reliance on "off-the-shelf" concepts and designs instead of site-specific understanding of the disturbance history, habitat conditions, and habitat-forming processes in individual rivers (Kondolf et al., 2003). Recognition that context-dependent physical and biological processes mediate the cascade of linkages between geology, geomorphology, and salmon ecology should provide the foundation for society's efforts to restore robust salmon populations.

Recent advances in understanding the geomorphology of forest channels in general and the historical ecology of Pacific Northwest rivers in particular have documented some of the effects of anthropogenic changes in geomorphologic processes and disturbance regimes on salmon populations. Ancient Scottish kings enforced salmon conservation laws aimed at protecting spawning salmon and their ability to access their spawning grounds long before the rise of modern science. Centuries worth of experience in managing salmon in Europe and New England (Montgomery, 2003) and recent landscape-level research (e.g., Montgomery et al., 1999; Rosenfeld et al., 2000; Pess et al., 2002) have shown that the processes that shape riverine habitat lead to strong associations between salmon populations and habitat availability, characteristics, and quality. Hence, it appears selfevident that salmon recovery efforts should be rooted in understanding of both hydro-geomorphic processes and historical changes to rivers and streams.

\section{GEOLOGY OF SALMON}

It is not surprising that fossil salmon are relatively rare given that they generally die in mountain streams, highenergy environments that do not tend to be preserved in the geologic record. Although long a subject of controversy, the recently resolved phylogeny of the Salmoninae (salmon and trout) and the timing of their diversification (Fig. 1) help explain two of the most basic (and curious) aspects of salmon biology: the diversity of the Pacific salmon relative to the Atlantic salmon, and their life history that involves spawning in fresh water, traveling to the sea, and then returning to rivers and streams to spawn (a life history trait referred to as anadromy).

The Atlantic and Pacific salmon are thought to have diverged from a common ancestor in the early Miocene after cooling of the Arctic Ocean isolated the Atlantic and Pacific populations (Stearly, 1992). Differences in resource availability between terrestrial and marine environments have been interpreted as the cause of the development of anadromy in general based on the observation that anadromous species are predominantly found in temperate latitudes where oceans are more productive than

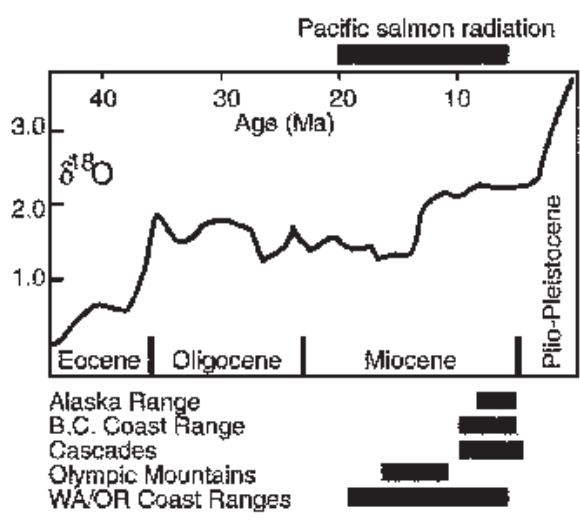

Figure 2. Relationship of radiation of Pacific salmon (top bar) to Miller et al.'s (1987) marine oxygen isotope curve and onset of uplift on Pacific Rim of North America (bottom bars). B.C.-British Columbia; WA/OR - Washington/Oregon. Adapted from Montgomery (2000). freshwater environments, whereas catadromous species, which migrate from the ocean to feed in fresh water, generally occur in tropical latitudes where oceans are less productive than river systems (Gross et al., 1988). Based on these ideas, Stearly (1992) proposed that global cooling in the Oligocene, which post-dates the earliest fossil of the Salmonidae the Eocene Eosalmo driftwoodensis from British Columbia (Wilson and Williams, 1992)], led to the development of anadromy in ancestral salmon prior to the Miocene divergence of the Atlantic and Pacific salmon. As the climate cooled and the productivity of freshwater ecosystems declined, increased marine productivity made an anadromous life history increasingly advantageous.
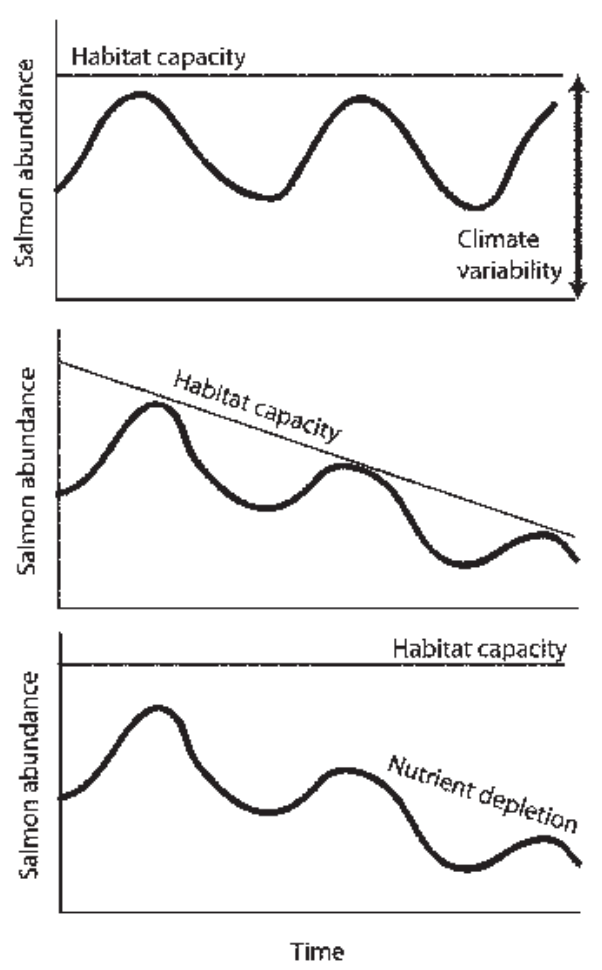

Figure 3. Potential relationships between salmon abundance, habitat capacity, and nutrient availability. Upper panel shows case of population dominantly controlled by variability in climate and marine conditions if habitat capacity is stable; middle panel shows the case of decreasing habitat capacity progressively ratcheting down population during periods of favorable climate; and lower panel shows the scenario wherein habitat is not limiting, due for example to nutrient depletion, loss of access, or excessive harvest. After Lawson (1993). 

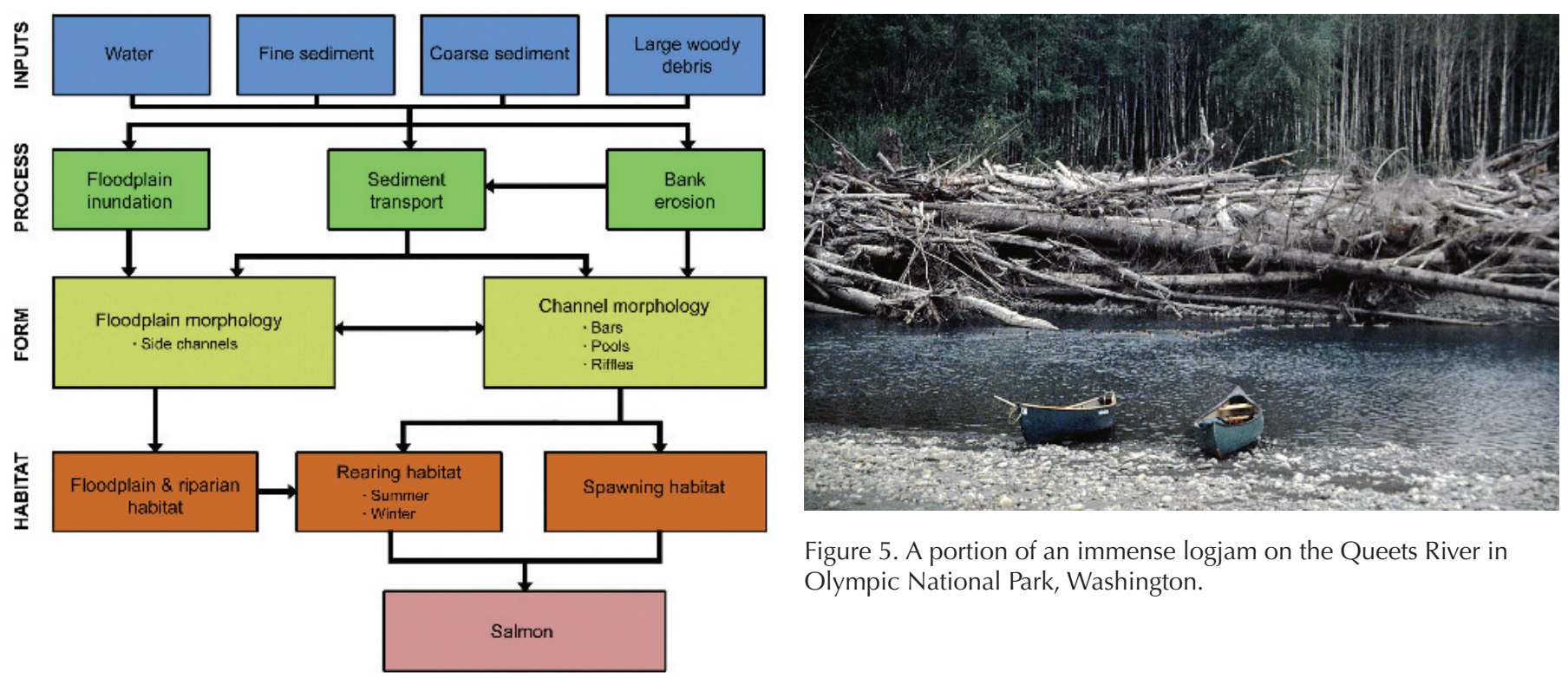

Figure 5. A portion of an immense logjam on the Queets River in Olympic National Park, Washington.

Figure 4. Generalized relationship of watershed inputs to channel processes, channel form, habitat characteristics, and salmon.

Whereas Atlantic salmon changed little in the past 20 m.y., Pacific salmon radiated into distinct species between 20 and $6 \mathrm{Ma}$ (McPhail, 1997). Although the local isolation of populations during Pleistocene glacial advances was thought to have triggered the diversification of salmon, fossil specimens of the modern species of salmon predate Pleistocene glaciations. In addition, DNA evidence shows that Pleistocene glaciation post-dates the radiation of the Pacific salmon (Thomas et al., 1986). The diversification of the Pacific salmon in the late Miocene does, however, coincide with the rise of coastal mountains on the west coast of North America (Fig. 2), and it has been hypothesized that the associated changes in the character of rivers and streams, rather than glaciation, triggered the radiation of the Pacific salmon (Montgomery, 2000). Moreover, a tectonic driver for the radiation of Oncorbynchus could explain the different evolutionary trajectories of the Atlantic and Pacific salmon, since there has been little physiographic change, other than that due to glaciation, in eastern North America since the divergence of the Atlantic and Pacific salmon.

As the landscape of the Pacific Northwest evolved, ancestral salmon populations adapted to the region's

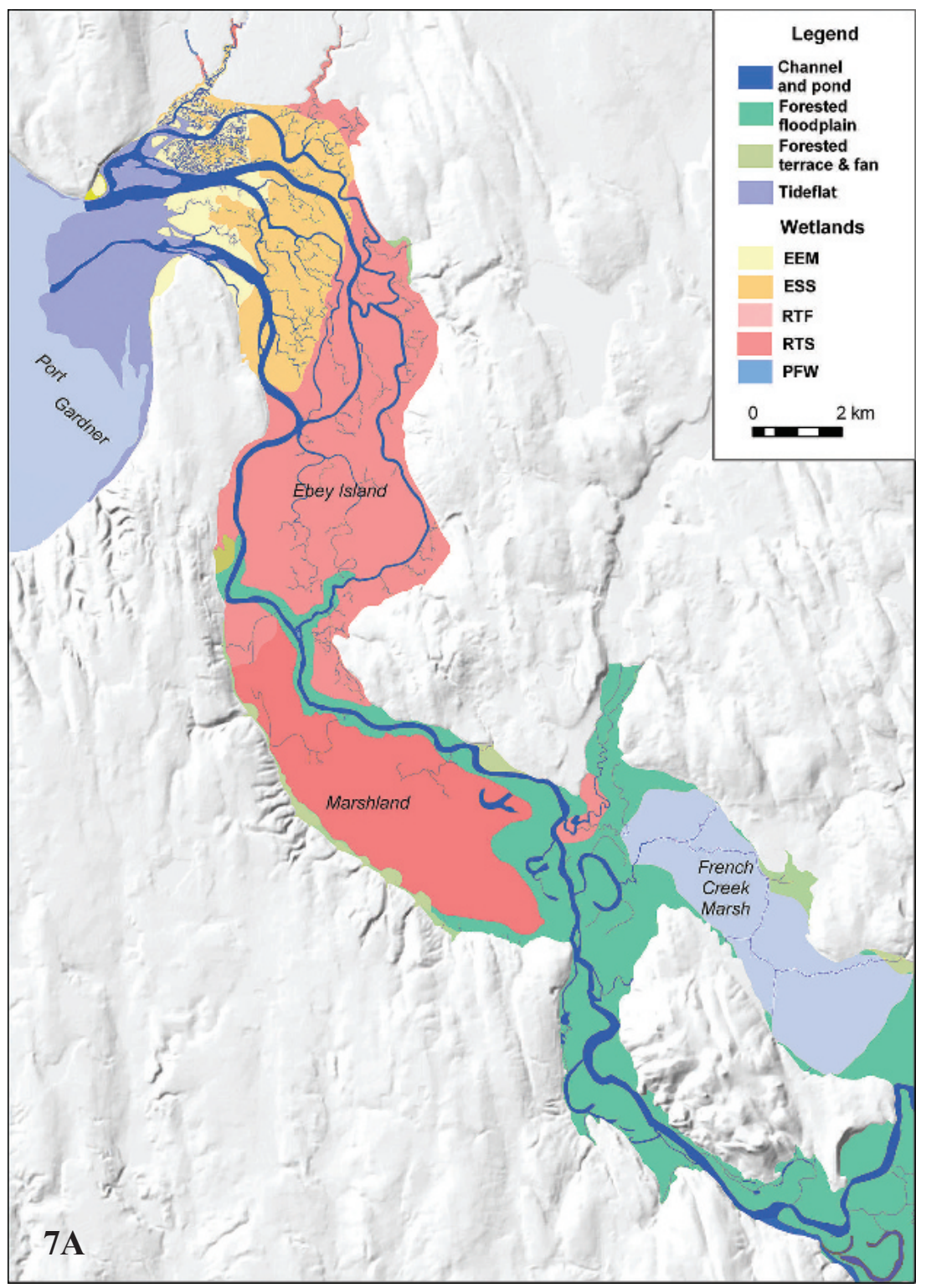



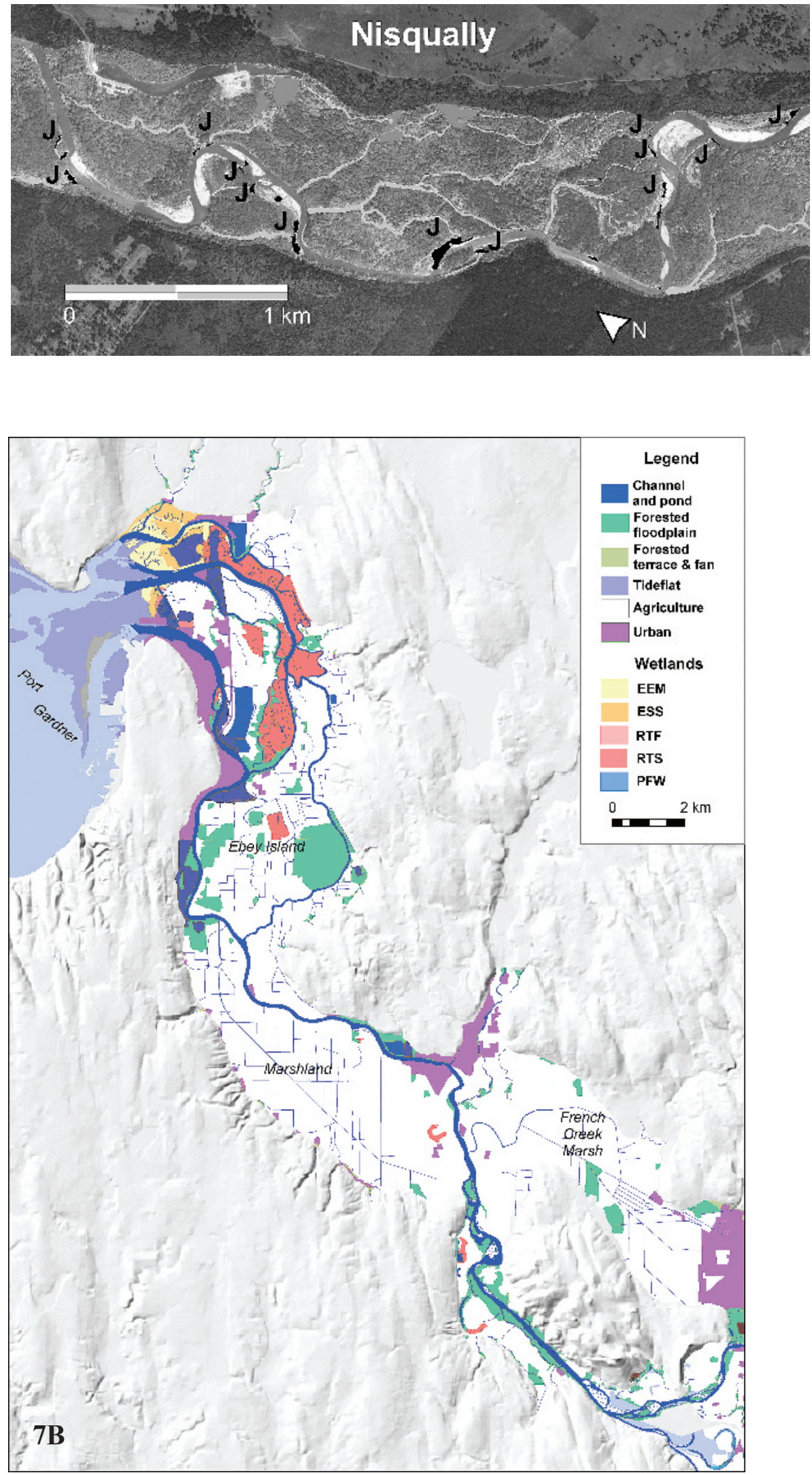

Figure 7 (on this and preceding page). Distribution of freshwater and estuarine habitat along the lower Snohomish River, Washington, (A) ca. 1870 and (B) 1990. EEM-estuarine emergent; ESS — estuarine scrub-shrub; RTF_riverine tidal forested; RTS—riverine tidal scrub-shrub; PFW-palustrine scrub-shrub. Updated by B. Collins after a map in Collins and Montgomery (2001).
Figure 6. Aerial photograph of a forested reach of the Nisqually River, Washington, illustrating the relationship between the location of large logjams (indicated by Js and black pattern) and inlets to perennial side channels (gray patterns). From Collins and Montgomery (2001).

changing rivers. Whether or not the diversification of habitat drove salmon speciation, it helped differentiate individual salmon runs as they spread into new streams and reaches in the evolving mountain drainage basins of the West Coast. Although different species of salmon may overlap in run timing and spawning areas, they generally tend to use different summer and winter rearing areas and spend different periods of time in freshwater and estuarine habitats. In general, chinook salmon ( $O$. tshawytscha) spawn in large mainstem rivers, coho salmon (O. kisutch) use smaller tributaries, sockeye salmon ( $O$. nerka) spawn in rivers in close proximity to lakes, and chum (O. keta) and pink salmon (O. gorbuscha) spawn in channels close to estuarine environments. Salmon adapted to their home streams to the extent that differences in run timing and spawning location both within and among river networks characterize different species and even various runs of the same species.

The initial divergence of coho, chinook, and chum salmon may represent adaptation to diversifying habitats in evolving coastal river systems of the Pacific Rim in which salmon runs began to specialize in using mainstem channels (chinook), smaller tributaries (coho), and estuarine habitats (chum) as these environments became increasingly distinct in terms of habitat characteristics while broad coastal plains became coastal mountains. In contrast to the wide geographic distribution of the other Pacific salmon, the range of sockeye salmon - the most recently evolved species of Pacific salmon-does not extend south of the southern extent of Pleistocene glaciation. This strong association with glaciated topography, where lakes are generally more abundant than in unglaciated topography, suggests that sockeye adapted to take advantage of lakes formed in deglaciated terrain. Consequently, the diver- 
gence of sockeye salmon well before the onset of Pleistocene glaciation suggests that they evolved near the northern end of their modern range during the late Miocene to early Pliocene onset of Northern Hemisphere glaciation 6 m.y. ago (Jansen and Sjøholm, 1991).

The dramatic influence of short-term climate variability on salmon abundance (e.g., Mantua et al., 1997; Finney et al., 2002) means that habitat availability defines a ceiling for population size, rather than a simple surrogate for population size. Freshwater ecosystems in the Pacific Northwest tend to be nutrient limited and biologists argue that a large modern nutrient deficit in freshwater systems of the Pacific Northwest may limit salmon population size to less than the available habitat could support (e.g., Gresh et al., 2000). Hence, even with long-term population records it can be difficult to assess whether habitat or nutrient limitations dominate observed variations in salmon abundance (Fig. 3). Nevertheless, it is clear that the amount and character of salmon habitat influences salmon abundance in Pacific Northwest rivers. It is also clear that human influences have radically altered the amount and character of salmon habitat in the United States over the past several centuries.

\section{GEOMORPHOLOGY OF SALMON}

In the early decades of the twentieth century, the new science of ecology focused on organisms and their environment, and particularly on how they influenced each other. For much of the second half of the century, however, the predominant view of ecosystems as either steady-state systems or as a oneway succession toward an equilibrium climax community downplayed the importance of geomorphology in governing ecosystem dynamics. Only near the end of the last century did recognition of the importance of disturbance regimes in shaping stream community composition and dynamics bring the role of hydro-geomorphological processes back into mainstream ecological theory (e.g., Pickett and White, 1985). Still, even though geomorphology can be considered a key control on ecosystem dynamics in a disturbance-driven view of the world (e.g., Swanson et al., 1988; Benda et al., 1998; Montgomery,
1999), the relative and absolute importance of the influences of geomorphological processes varies among species.

Salmon habitat is influenced by landscape processes that govern the supply and movement of water, sediment, and wood to and through their rivers and streams (Fig. 4). Salmon runs rely on rivers to provide particular kinds of habitat suitable for spawning, to foster the development of their eggs while buried in streambed gravel, and to shelter their young while they grow, forage, and hide from predators as they run down to the sea (Bjornn and Reiser, 1991). On their way back upriver, returning adults also need deep, sheltered pools in which to rest and clean gravel in which to spawn. A general understanding of salmon ecology therefore rests on understanding the watershed and fluvial processes that create, sustain, and destroy salmon habitat (Swanston, 1991).

At the most general level, nonmarine salmon habitat can be generalized into spawning habitat, summer rearing habitat, and winter rearing habitat. The size of spawning gravel, and therefore their preferred spawning grounds, varies for different salmonids, with larger salmon generally spawning in the coarser substrate of larger channels (Kondolf and
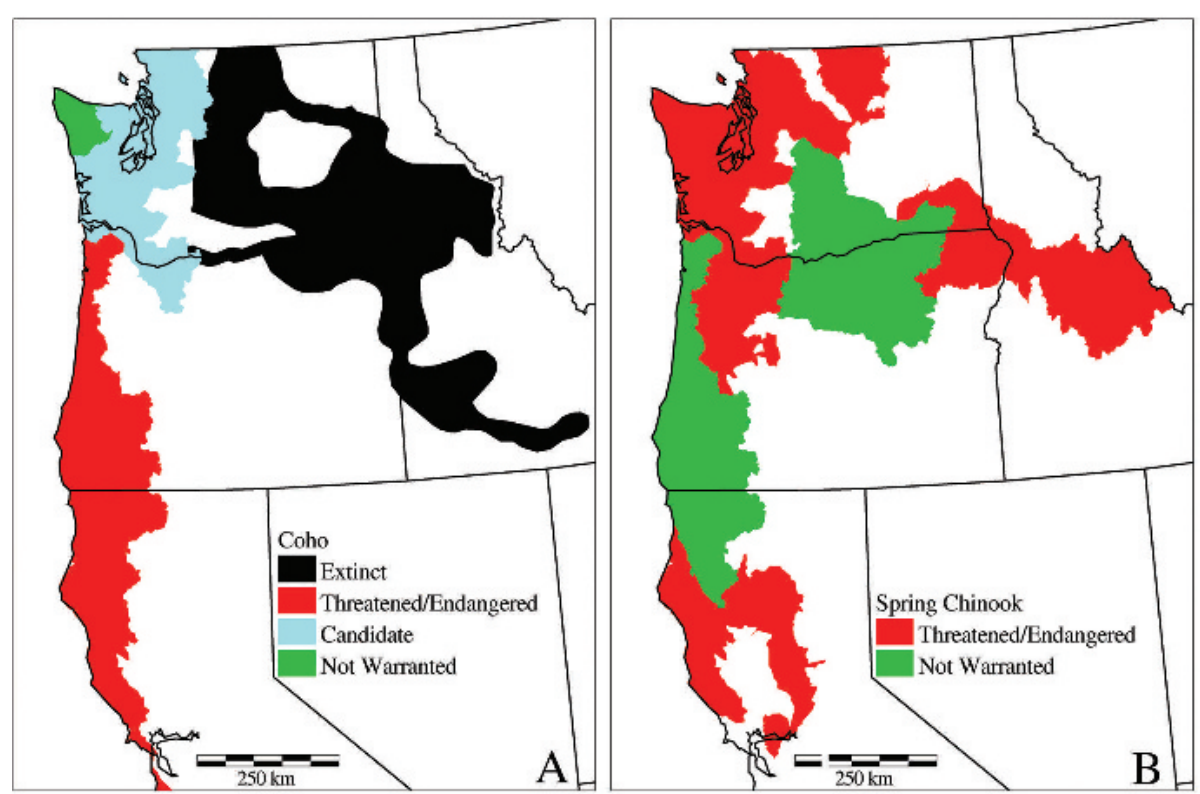

Figure 8. Federal status of (A) coho and (B) spring chinook salmon runs in the western United States, according to the National Marine Fisheries Service (NMFS) as of June 2003. Former extent of now extinct coho salmon runs was digitized from Frissell (1993). NMFS data can be found at www.nwr.noaa.gov/1 salon/salmesa/cohoesum.htm for coho and at www.nwr.noaa.gov/1 salon/salmesa/chinesum.htm for chinook.
Wolman, 1993). Ideally, spawning habitat includes both appropriately sized gravel and proximity to pools that provide sheltered resting areas. In addition, large fish use deep pools to rest in on their way back upriver to spawn. Pools formed by the interaction of high flows and sediment transport scour into bedrock and flow around stable logs and logjams, providing different types and qualities of summer habitat for juvenile salmon (May and Lee, 2004). Off-channel wetlands and floodplain side channels can provide both summer rearing habitat and refugia from winter high flows (Peterson and Reid, 1984).

The importance of freshwater habitat abundance and quality varies among species of Pacific salmon. Pink and chum salmon, for example, do not spend much time in fresh water, as juveniles migrate to estuarine environments soon after emerging from the gravel. Consequently, the condition of estuarine habitat generally exerts a greater influence on pink and chum salmon runs than does the condition of freshwater habitats. In contrast, juvenile coho and chinook salmon rear for one to two years in rivers and streams before migrating to the marine environment. Consequently, these species are much 
more strongly dependent on the condition of rivers and streams, and their abundance has been related to habitat abundance and conditions across a wide range of scales from differences between pools and riffles (Rosenfeld, 2000) to reach-scale differences in channel type and pool frequency (Montgomery et al., 1999), and watershed-scale patterns of land use (Pess et al., 2002).

Over the past century and a half, many of the changes in the character of salmon habitat in the rivers and streams of the Pacific Northwest resulted either directly or indirectly from loss of stable in-channel wood debris (Fig. 5). The huge trees of the Pacific Northwest's native forests greatly influenced the region's rivers and played important roles in shaping salmon habitat. Historical changes in the size and supply of the wood delivered to rivers and streams changed sediment routing and storage, channel dynamics and processes, and even channel morphology. Many of the geomorphic effects of wood in rivers arise from the influence of "key" pieces of wood large enough to obstruct flow and sediment transport, and thereby stabilize other debris in logjams. Commonly recognized effects of wood on aquatic habitat are manifest at the scale of individual habitat units such as bars and pools (Bisson et al., 1982), but these local influences can generate emergent properties at larger spatial scales by collectively controlling the morphology of channel reaches and valley bottoms. Field surveys of forest channels have shown that the frequency of pools, many particulars of channel morphology such as channel width, the style and distribution of alluvial bedforms, and in places even the extent of gravel streambeds are controlled by the abundance of large logs and logjams (e.g., Keller and Swanson, 1979; Robison and Beschta, 1990; Montgomery et al., 1995; 1996; 2003). In addition, a number of workers have noted how an abundant supply of large wood can split flow into multiple channels and maintain complex, anastomosing channel patterns on forested floodplains unconfined by valley walls (Sedell and Froggatt, 1984; Harwood and Brown, 1993; Abbe and Montgomery, 1996;
Collins and Montgomery, 2001; Collins et al., 2002; O'Connor et al., 2003) (Fig. 6). These large-wood-mediated habitat characteristics made Pacific Northwest rivers natural salmon factories with spawning gravel located in proximity to deep pools for summer rearing, and sheltered floodplain side-channels for winter rearing.

In the decades after the Civil War, the U.S. government embarked on an extensive national program of removing snags from rivers to promote economic development because logs and logjams impeded navigation, and therefore commerce (Ruffner, 1886). The U.S. Army Corps of Engineers recorded pulling more than 65,000 snags from the Willamette River from 1870 to 1950 (Sedell and Froggatt, 1984), and more than 150,000 snags from five Puget Sound rivers since the 1880s (Collins and Montgomery, 2001). As development spread inland and up rivers, valley bottom wetlands were drained and riparian forests were cleared for agriculture, reducing the supply of large trees that could erode into rivers and become new snags (Fig. 7). Studies of the historical characteristics of valley bottoms around Puget Sound also show that the loss of stable logs and logjams converted complex channel forms to simpler channel patterns (Collins and Montgomery, 2001; Collins et al., 2003). Preliminary estimates of the loss of different kinds of salmon habitat from Puget Sound watersheds range from a third to more than two-thirds (Beechie et al., 1994, 2003; Collins and Montgomery, 2001).

An understanding of the extent and effects of anthropogenic changes in watershed processes on salmon habitat adequate for developing strategies for restoring salmon requires answering the questions of what were the rivers like that salmon evolved in, how did salmon habitat and habitat-forming processes change, and what opportunities exist (or can be made) for reversing these changes. Too often, however, river and stream restoration projects are based on ideas or technologies transferred from different geomorphologic contexts and applied in inappropriate situations. Yet understanding the extent of historical anthropogenic modifications to the river systems to which par- ticular runs of salmon adapted can help guide strategies for restoring rivers and promoting salmon recovery.

\section{RESTORATION ECOLOGY OF SALMON}

The evolutionary linkages between landscape processes and salmon have implications for the response of salmon populations to human modifications of watershed processes because salmon evolved in response to geologic and geomorphologic disturbances that differ in character, frequency, and scale from common anthropogenic disturbances. Many natural disturbance processes can be characterized as pulse disturbances, wherein episodic, short-duration disturbance is followed by return to a former state. A key question for salmon restoration efforts is whether a species evolved to respond to infrequent geological disturbances (e.g., glaciations and volcanic eruptions) and more frequent geomorphological disturbances (e.g., floods and landslides) that tend to be spatially asynchronous has the ability to adapt to sustained, regionally synchronous anthropogenic disturbances.

The salmon's life history trait of spending 3-5 yr at sea is well suited for an environment characterized by periodic, but still relatively infrequent, disturbances such as floods and landslides because the bulk of their population is at sea at any one time. However, salmon are ill-equipped to endure anthropogenically induced changes in disturbance regimes that turn formerly infrequent disturbances into frequent (press) disturbances. For example, a shift in the recurrence interval of bed scouring high flow events could turn a formerly pulse disturbance into a press disturbance because egg-to-fry survival is inversely related to the recurrence interval of winter high flows (e.g., Beamer and Pess, 1999). In some densely developed areas of the Puget Lowland where the preurbanization 10-yr discharge became the post-urbanization 2-yr discharge (Booth, 1990), fall-spawning salmon were displaced by cutthroat trout that spawn in the spring (Lucchetti and Fuerstenberg, 1992), a time when their eggs are generally safe from high flows.

Debris flows provide another example of a catastrophic pulse disturbance that has become more frequent 
in many watersheds as a result of forest management. The direct and indirect effects of debris flows can adversely impact salmonids, but debris flow-deposited logjams can act as habitat forming agents (Everest and Meehan, 1981). Although it is well established that forest clearing on steep slopes increases rates of landsliding (Sidle et al., 1985), far less is known about the net effects on salmon populations other than the obviously high mortality among fish in the channel at the time of a debris flow. However, it is likely that with increasing disturbance frequency, the negative effects of such disturbances increasingly overshadow the positive effects due to habitat formation.

In addition to changes in disturbance regimes, historical anthropogenic effects on salmon habitat include reduced extent and quality of spawning gravel, channel incision due to removal of stable logs and logjams, fewer pools to provide summer rearing habitat, loss of off-channel wetlands and floodplain sloughs that provided winter rearing habitat, increased bed scour, and loss of access to habitat due to blockage by dams. The relative importance of these different effects on salmon habitat depends on the geology, geomorphology, and disturbance history of specific watersheds.

The regional pattern to the distribution of threatened and endangered runs of coho and chinook salmon (Fig. 8) illustrates how broad views of changes in the geomorphology can help focus questions pertinent to restoration strategies and efforts. Spring runs of chinook salmon in Oregon and Washington are considered threatened or endangered in Puget Sound, the Willamette Valley, coastal Washington, but are not considered at risk of extinction in coastal Oregon and the central Columbia River basin. In contrast, coho salmon runs are extinct in the Columbia River basin (Frissell, 1993), are considered threatened or endangered in coastal Oregon, and are a candidate for listing in western Washington. In addition to the effect of dams on the Columbia River system, the difference in these patterns probably reflects the extensive floodplain modifications, gravel mining, and the loss of side channels and freshwater wetlands along large rivers and floodplain habitats used by chinook salmon in the Puget Sound region and Willamette Valley, and the extensive impacts of splash damming and forestry to the smaller streams used by coho salmon on the Oregon Coast.

Through direct and indirect influences on landscape dynamics, geology and geomorphology affect salmon over a remarkable range of spatial and temporal scales (Fig. 9). Yet, understanding of how specific changes in fluvial and watershed processes influence salmon habitat, as well as salmon themselves, is necessary to confidently align management actions with policy goals. While it would appear obvious that it would be difficult to predict the outcome of management policies aimed at a complex system that we do not understand, even a relatively complete understanding of a natural system does not guarantee optimal resource management. Still, in addressing natural systems characterized by high uncertainty or natural variability, an understanding of both past system behavior and the processes that govern that behavior is necessary to guide confident management decisions.

\section{GEOMORPHOLOGY AND RESTORATION ECOLOGY}

It is well known that an understanding of salmon ecology requires understanding habitat conditions. Each summer, a small army of biologists, foresters, and fishery technicians document habitat characteristics in salmon streams and rivers throughout the Pacific Northwest. Increasingly, geomorphologists participate on such teams, and the growing recognition of the need to involve geomorphologists in habitat assessments and the design of restoration projects is helping to develop and define the professional practice of restoration geomorphology.

Successful river restoration projects aimed at promoting salmon recovery require an understanding of a watershed and its disturbance history, including the effects or legacies of human actions. Although in simple cases such as removing or modifying salmon-blocking culverts or dams, the solution may be obvious (even if not politically feasible), in many cases the diagnosis of restoration issues and design of projects to address them are complex and subjective. Integrating the linked influences of hydro-geomorphologic and biological processes often requires synthetic thinking and analyses beyond solving a simple set of closed equations or adopting a standard view or conceptual model. Montgomery and MacDonald (2002) argued that one-size-fits-all channel classifications and restoration guidelines are of limited utility when ap-

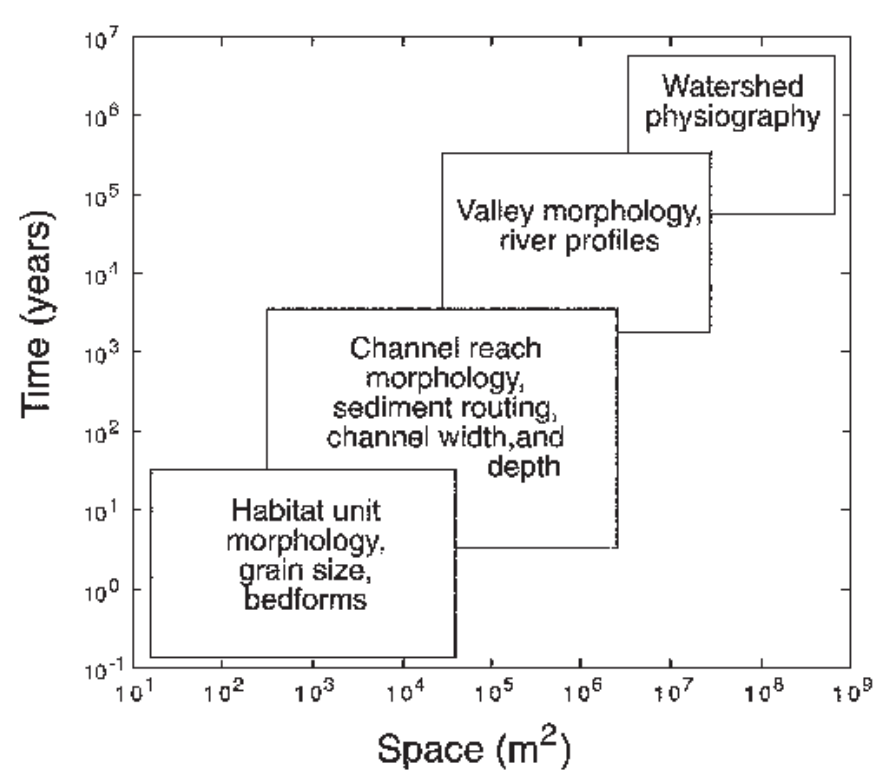

Figure 9. Spatial and temporal scales across which geology and geomorphology influence aspects of salmon habitat. 
plied without an understanding of both disturbance history and spatial context within a watershed. Although most professional geomorphologists would agree that restoration design work should be approached cautiously and with the appropriate expertise, the issue of what qualifications and training are necessary to engage professionally in applied fluvial geomorphology is only now beginning to receive the attention it deserves in the scientific community. Yet in applying geomorphology to salmon recovery it is important to guard against the sometimes-naive presumption that professionals in other disciplines (such as hydrologists, foresters, ecologists, and engineers) can reliably provide accurate geomorphologic insight.

Given the importance of context in diagnosing and assessing habitat conditions, geomorphologists are needed to help assess the causes of problems and evaluate potential solutions in restoration ecology, much like how geologists are recognized as essential for scoping problems and evaluating potential solutions in geotechnical engineering. It should not be controversial to maintain that an understanding of the extent and cause of anthropogenic impacts on salmon habitat should be central to devising potential measures to reverse or mitigate such effects. In practice, however, many habitat restoration projects are based on standardized approaches and designs or the application of simple generalized conceptual models for what a stream should be like. Although geomorphologists can contribute to restoration ecology by bringing technical expertise to bear on specific problems, an equally important contribution lies in providing the perspective that an appreciation of spatial and temporal context brings to a site-specific understanding of habitat conditions and habitat-forming processes.

The stories of declining salmon runs are remarkably parallel across the English-speaking world, from the rivers of the Pacific Northwest to New England and before that Great Britain (Montgomery, 2003). In each case, the history of salmon records how changes to rivers and their watersheds gradually remade river basins into regions inhospitable to salmon over time spans far longer than social and political pro- cesses last. In the past, the mismatched time scales over which societal and geomorphologic processes operate have proven problematic for salmon. Today, as society focuses substantial human and economic resources on efforts to restore salmon runs, geomorphologic expertise is essential for ensuring that money and effort are well spent on specific projects and that restoration practices are aligned with strategic policy objectives.

\section{ACKNOWLEDGMENTS}

I thank Yvonne Martin, Tom Lisle, Bill Dietrich, Gordon Grant, Sara Mitchell, and Amanda Henck for their helpful comments and suggestions on a draft manuscript, Harvey Greenberg and Charles Kiblinger for help with creating figures, Brian Collins for providing his updated map of habitat change along the Snohomish River, and Ray Troll for allowing me to use his wonderful artwork.

\section{REFERENCES CITED}

Abbe, T.B., and Montgomery, D.R., 1996, Interaction of large woody debris, channel hydraulics and habitat formation in large rivers: Regulated Rivers: Research Management, v. 12, p. 201-221, doi: 10.1002/(SICI)10991646(199603)12:2/33.3.CO;2-1.

Beamer, E.M., and Pess, G.R., 1999, Effects of peak flows on Chinook (Oncorhynchus tshawytscha) spawning success in two Puget Sound river basins, in Sakrison, R., and Sturtevant, P., eds., Watershed Management to Protect Declining Species: Middleburg, American Water Resources Association, p. 67-70.

Beechie, T.J., Beamer, E., and Wasserman, L., 1994 Estimating coho salmon rearing habitat and smolt production losses in a large river basin, and implications for restoration: North American Journal of Fisheries Management, v. 14, p. 797-811, doi: 10.1577/15488675(1994)0142.3.CO;2.

Beechie, T.J., Pess, G., Beamer, E., Lucchetti, G., and Bilby, R.E., 2003, Role of watershed assessments in recovery planning, in Montgomery, D.R., et al., Restoration of Puget Sound Rivers: Seattle, University of Washington Press, p. 194-225.

Benda, L.E., Miller, D.J., Dunne, T., Reeves, G.H., and Agee, J.K., 1998, Dynamic landscape systems, in Naiman, R. J., and Bilby, R. E., River Ecology and Management: Lessons from the Pacific Coastal Ecoregion: New York, Springer-Verlag, p. 261-288.

Bisson, P.A., Nielson, J.L., Palmason, R.A., and Gore, L.E., 1982, A system of naming habitat types in small streams, with examples of habitat utilization by salmonids during low stream flow, in Armantrout, N.B., ed., Acquisition and Utilization of Aquatic Habitat Information: Portland, Western Division, American Fisheries Society, p. 62-73.

Bjornn, T.C., and Reiser, D.W., 1991, Habitat requirements of salmonids in streams, in Meehan, W.R., ed., Influences of Forest and Rangeland Management on Salmonid Fishes and Their Habitats: Bethesda, American Fisheries Society Publication 19, p. 83-138.

Booth, D., 1990, Stream channel incision following drainage basin urbanization: Water Resources Bulletin, v. 26, p. 407-417.

Collins, B.D., and Montgomery, D.R., 2001, Importance of archival and process studies to characterizing pre-settlement riverine geomorphic processes and habitat in the Puget Lowland, in Dorava, J.B., et al., eds., Geomorphic Processes and Riverine Habitat: Washington, D.C.,
American Geophysical Union, p. 227-243.

Collins, B.D., Montgomery, D.R., and Haas, A., 2002, Historic changes in the distribution and functions of large woody debris in Puget Lowland rivers: Canadian Journal of Fisheries and Aquatic Sciences, v. 59, p. 66-76, doi: 10.1139/F01-199.

Collins, B.D., Montgomery, D.R., and Sheikh, A.J., 2003, Reconstructing the historic riverine landscape of the Puget Lowland, in Montgomery, D.R., et al., eds., Restoration of Puget Sound Rivers: Seattle, University of Washington Press, p. 79-128.

Everest, F.H., and Meehan, W.R., 1981, Forest management and anadromous fish habitat productivity, in Sabol, K., ed., Transactions of the Forty-Sixth North American Wildlife and Natural Resources Conference: Washington, D.C., Wildlife Management Institute, p. 521-530.

Finney, B.P., Gregory Eaves, I., Douglas, M.S.V., and Smol, J.P., 2002, Fisheries productivity in the Northeastern Pacific Ocean over the past 2,200 years: Nature, v. 416, p. 729-733.

Frissell, C.A., 1993, Topology of extinction and endangerment of native fishes in the Pacific Northwest and California (U.S.A.): Conservation Biology, v. 7, p. 342-354, doi: 10.1046/J.1523-1739.1993.07020342.X.

Gresh, T., Lichatowich, J., and Schoonmaker, P., 2000, An estimation of historic and current levels of salmon production in the Northeast Pacific Ecosystem: Evidence of a nutrient deficit in the freshwater systems of the Pacific Northwest: Fisheries, v. 25, no. 1, p. 15-21, doi: 10.1577/ 1548-8446(2000)0252.0.CO;2.

Gross, M.R., Coleman, R.M., and McDowall, R.M., 1988, Aquatic productivity and the evolution of diadromous fish migration: Science, v. 239, p. 1291-1293.

Harwood, K., and Brown, A.G., 1993, Fluvial processes in a forested anastomosing river: Flood partitioning and changing flow patterns: Earth Surface Processes and Landforms, v. 18, p. 741-748.

Jansen, E., and Sjøholm, J., 1991, Reconstruction of glaciation over the past $6 \mathrm{Myr}$ from ice-borne deposits in the Norwegian Sea: Nature, v. 349, p. 600-603, doi: 10.1038/ 349600A0.

Keller, E.A., and Swanson, F.J., 1979, Effects of large organic material on channel form and fluvial processes: Earth Surface Processes, v. 4, p. 361-380.

Kondolf, G.M., and Wolman, M.G., 1993, The sizes of salmonid spawning gravels: Water Resources Research, v. 29, p. 2275-2285, doi: 10.1029/93WR00402.

Kondolf, G.M., Montgomery, D.R., Piégay, H., and Schmitt, L., 2003, Geomorphic classification of rivers and streams, in Kondolf, G.M., and Piégay, H., eds., Tools in Fluvial Geomorphology: Chichester, John Wiley \& Sons, p. 171-204. Lawson, P.W., 1993, Cycles in ocean productivity, trends in habitat quality, and the restoration of salmon runs in Oregon: Fisheries, v. 18, no. 8, p. 6-10, doi: $10.1577 /$ 1548-8446(1993)0182.0.CO;2.

Lucchetti, G., and Fuerstenberg, R., 1992, Urbanization, habitat conditions and fish communities in small streams of west King County, Washington, USA, with implications for management of wild coho salmon: 1992 Coho Salmon Workshop, Nanaimo, Canada.

Mantua, N.J., Hare, S.R., Qhang, Y., Wallace, J.M., and Francis, R.C., 1997, A Pacific interdecadal climate oscillation with impacts on salmon production: Bulletin of the American Meteorological Society, v. 78, p. 1069-1079.

May, C.L., and Lee, D.C., 2004, The relationships among in-channel sediment storage, pool depth, and summer survival of juvenile salmonids in Oregon Coast Range streams: North American Journal of Fisheries Management, v. 24, p. 761-774, doi: 10.1577/M03-073.1.

McPhail, J.D., 1997, The origin and speciation of Oncorhynchus revisited, in Stouder, D.J., et al., eds., Pacific Salmon and Their Ecosystems: Status and Future Options: New York, Chapman and Hall, p. 29-38.

Miller, K.G., Fairbanks, R.G., and Mountain, G.S., 1987 Tertiary oxygen isotope synthesis, sea level history and continental margin erosion: Paleoceanography, v. 2, p. 6829-6848.

Montgomery, D.R., 1999, Process domains and the river continuum: Journal of the American Water Resources Association, v. 35, p. 397-410. 
Montgomery, D.R., 2000, Coevolution of the Pacific salmon and Pacific Rim topography:

Geology, v. 28, p. 1107-1110, doi: 10.1130/00917613(2000)0282.3.CO;2.

Montgomery, D.R., 2003, King of Fish: The Thousand-Year Run of Salmon: Boulder, Colorado, Westview Press, 290 p. Montgomery, D.R., and MacDonald, L.H., 2002, Diagnostic approach to stream channel assessment and monitoring: Journal of the American Water Resources Association, v. 38, p. 1-16

Montgomery, D.R., Buffington, J.M., Smith, R., Schmidt, K., and Pess, G.G., 1995, Pool spacing in forest channels: Water Resources Research, v. 31, p. 1097-1105.

Montgomery, D.R., Abbe, T.B., Peterson, N.P., Buffington, J.M., Schmidt, K., and Stock, J.D., 1996, Distribution of bedrock and alluvial channels in forested mountain drainage basins: Nature, v. 381 , p. 587-589, doi: 10.1038 381587A0

Montgomery, D.R., Pess, G., Beamer, E.M., and Quinn, T.P., 1999, Channel type and salmonid spawning distributions and abundance: Canadian Journal of Fisheries and Aquatic Sciences, v. 56, p. 377-387, doi: 10.1139/CJFAS-56-3-377.

Montgomery, D.R., Massong, T.M., and Hawley, S.C.S. 2003, Debris flows, log jams, and the formation of pools and alluvial channel reaches in the Oregon Coast Range: Geological Society of America Bulletin, v. 115, p. 78-88, doi: 10.1130/0016-7606(2003)1152.0.CO;2.

Nehlsen, W., Williams, J.E., and Lichatowich, J.A., 1991, Pacific salmon at the crossroads: Stocks at risk from California, Oregon, Idaho, and Washington: Fisheries, v. 16 , no. 2 , p. 4-21, doi: $10.1577 / 1548$ 8446(1991)0162.0.CO;

O'Connor, J.E., Jones, M.A., and Haluska, T.L., 2003, Flood plain and channel dynamics of the Qunault and Queets rivers, Washington, USA: Geomorphology, v. 51, p. 31-59, doi: 10.1016/S0169-555X(02)00324-0.
Pess, G.R., Montgomery, D.R., Bilby, R.E., Steel, A.E., Feist, B.E., and Greenberg, H.M., 2002, Landscape characteristics, land use, and coho salmon (Oncorhynchus kisutch) abundance, Snohomish River, Washington State, USA: Canadian Journal of Fisheries and Aquatic Sciences, v. 59, p. 613-623, doi: 10.1139/F02-035.

Peterson, N.P., and Reid, L.M., 1984, Wall-base channels: their evolution, distribution and use by juvenile coho salmon in the Clearwater River, Washington, in Walton, J.M and Houston, D.B., Proceedings of the Olympic Wild Fish Conference: Port Angeles, p. 215-226.

Pickett, S.T.A., and White, P.S., 1985, The Ecology of Natural Disturbance and Patch Dynamics: New York, Academic Press, 472 p.

Robison, E.G, and Beschta, R.L., 1990, Coarse woody debris and channel morphology interactions for undisturbed streams in southeast Alaska, USA: Earth Surface Processes and Landforms, v. 15, p. 149-156.

Rosenfeld, J., 2000, Effects of fish predation in erosional and depositional habitats in a temperate stream: Canadian Journal of Fisheries and Aquatic Sciences, v. 57, p. 13691379, doi: 10.1139/CJFAS-57-7-1369.

Rosenfeld, J., Porter, M., and Parkinson, E., 2000, Habita factors affecting the abundance and distribution of juvenile cutthroat trout (Oncorhynchus clarki) and coho salmon (Oncorhynchus kisutch): Canadian Journal of Fisheries and Aquatic Sciences, v. 57, p. 766-774, doi: 10.1139/CJFAS57-4-766.

Ruffner, E.H., Capt., 1886, The Practice of the Improvement of the Non-tidal Rivers of the United States, with an Examination of the Results Thereof: New York, John Wiley \& Sons, $195 p$

Sedell, J. R. and Froggatt, J. L., 1984, Importance of streamside forests to large rivers: the isolation of the Willamette River, Oregon, U.S.A., from its floodplain by snagging and streamside forest removal: Verhandlungen-Internationale
Vereinigung für Theoretifche und Angewandte Limnologie, v. 22 , p. $1828-1834$

Sidle, R.C., Pearce, A.J., and O'Loughlin, C.L., 1985 Hillslope Stability and Land Use: Washington, D.C. American Geophysical Union, 140 p.

Stearly, R.F., 1992, Historical ecology of Salmoninae with special reference of Oncorhynchus, in Mayden, R.L., ed , Systematics, Historical Ecology, and North American Freshwater Fishes: Stanford, Stanford University Press, p. 622-658.

Stearly, R.F., and Smith, G.R., 1993, Phylogeny of the Pacific trouts and salmons (Oncorhynchus) and genera of the family Salmonidae: American Fisheries Society Transactions, v. 122, p. 1-33, doi: 10.1577/15488659(1993)1222.3.CO;2.

Swanson, F.J., Kratz, T.K., Caine, N., and Woodmansee, R.G., 1988, Landform effects on ecosystem patterns and processes: Bioscience, v. 38, p. 92-98.

Swanston, D.N., 1991, Natural processes, in Meehan, W.R. ed., Influences of Forest and Rangeland Management on Salmonid Fishes and Their Habitats: Bethesda, American Fisheries Society, p. 139-179.

Thomas, W.K., Withler, R.E., and Beckenback, A.T., 1986 Mitochondrial DNA analysis of Pacific salmon evolution: Canadian Journal of Zoology, v. 64, p. 1058-1064.

Wilson, M.V.H., and Williams, R.R.G., 1992, Phylogenetic, biogeographic, and ecological significance of early fossil records of North American freshwater teleostean fishes, in Mayden, R.L., ed., Systematics, Historical Ecology, and North American Freshwater Fishes: Stanford, Stanford University Press, p. 224-244

Manuscript received June 22, 2004, accepted September 17, 2004.
THE GEOLOGICAL SOCIETY OF AMERICA

\section{Available through the GSA BOOKSTORE!}

Sorry, no additional discounts on other publishers' books.

\section{King of Fish}

by Dave Montgomery, 2003

Published by Westview/Perseus KINGOFFISH, ISBN 0813341477 hardbound, $\$ 26.00$

\section{Krakatoa}

by Simon Winchester, 2003

Published by HarperCollins

KRAKATOA, ISBN 0066212855

hardbound, $\$ 25.95$

\section{Seashell on the Mountaintop}

by Alan Cutler, 2003

Published by Dutton/Penguin Group USA

SEASHELL, ISBN 0525947086 hardbound, $\$ 23.95$

\section{The Man Who} Found Time by Jack Repcheck Published by Westview/Perseus MANWHOFOUND, ISBN 073820692X, hardbound, $\$ 26.00$

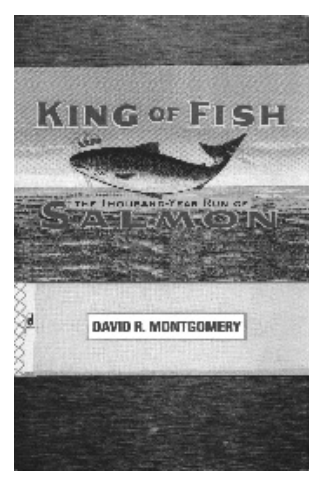

B A R R E N

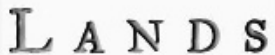

by Kevin Krajick, 2001

Published by Holtzbrinck

BARRENLANDS, ISBN 0805071857,

softcover, $\$ 16.00$

The Map That Changed the World

by Simon Winchester, 2001

Published by HarperCollins

THEMAP, ISBN 0060931809 ,

softcover, \$13.95
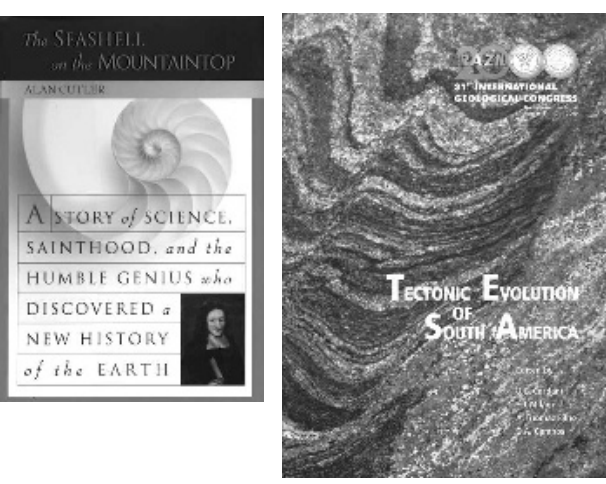

Annals of the Former World

by John McPhee, 2000

Published by Farrar, Strauss \& Giroux New York, N.Y.

OPBO14, 704 p., ISBN 0-37451-873-4, softcover, $\$ 18.00$

\section{Tectonic Evolution of} South America

Edited by U.G. Cordani, E.J. Milani, A. Thomaz Filho, and D.A. Campos, 2000 OPB019, 854 p., ISBN 85-901482-1-1 softcover, $\$ 60.00$ (303) 357-1000, option 3 • 1-888-443-4472 • Fax 303-357-1071 